\title{
Prospects for US-Cuba Cooperation in Gastroenterology, Hepatology and Liver Transplantation
}

\author{
Marlen I. Castellanos-Fernández MD PhD, Mirtha Infante-Velázquez MD PhD, Enrique Arús-Soler MD PhD, \\ Marcelo Kugelmas MD FAASLD FACP, Ramón Bataller MD PhD, Ramón Villamil-Martínez MD, Zaily Dorta-Guridi MD PhD, \\ Caridad Ruenes-Domenech MD MS
}

\begin{abstract}
Gastroenterology, hepatology and liver transplant exchanges between the USA and Cuba have mainly consisted of scientific events and short visits. This has facilitated Cuba's inclusion in recognized scientific organizations, familiarity with Cuba's biotech products for treatment of liver disease, and access by Cuban professionals to the highest level of scientific information for clinical practice. It has also given health professionals in the US a more accurate picture of Cuba's health sector. The results of the Global Alcoholic Liver Disease Survey, which included Cuba and was designed and coordinated in
\end{abstract}

\section{INTRODUCTION}

Chronic liver disease is a serious global health issue. Global deaths due to hepatic cirrhosis increased from some 676,000 in 1980 to $>1,000,000$ in 2010 , and the mortality rate increased by $10.3 \%$ between 2005 and 2015. Average prevalence of autopsy-detected hepatic cirrhosis is $\leq 10 \%$, but this is likely an underestimate, since one third of patients are asymptomatic for many years. The main causes of cirrhosis are alcohol, nonalcoholic fatty liver disease and viral hepatitis, which occur in all countries, regardless of geography or level of economic development. These diseases have enormous health and social costs, including direct health care expenses and indirect costs from productive years of life lost. It is estimated that viral hepatitis causes $53 \%$ of hepatic cirrhosis and $54 \%$ of liver cancers.[1-3]

In the USA, the burden of chronic liver diseases is substantial and has been increasing. The National Health and Nutrition Examination Survey, conducted between 1999 and 2010, estimated cirrhosis prevalence at $0.27 \%$, or 633,323 adults. Diabetes, alcohol abuse, hepatitis $B$ and $C$, male sex and old age were independently associated with cirrhosis. The first three factors contributed to $53.5 \%$ of cases.[4] Age-adjusted mortality from chronic liver disease and cirrhosis increased from 9.6 per 100,000 in 1999 to 10.2 per 100,000 in 2013 (with more marked increase in the group aged $55-64$ years), making it the 12th leading cause of death in 2013 (1.4\% of all deaths). [5] Research and interventions to improve patient health are needed.

In Cuba, cirrhosis and chronic liver disease have been the 9th and 10th leading causes of death in the last 20 years; taken together, they have the second highest mortality rate among digestive

IMPORTANCE Progress in hepatology and liver transplantation has helped Cuba overcome great health challenges. Unique models have been established for future collaborations that will benefit both countries. the USA, opened doors to joint research and scientific publications. Until now, there have been no protocols for ongoing cooperation to enable bilateral clinical trials or continuing professional development in diagnostic, therapeutic and surgical techniques for hepatology and liver transplantation. There are many mutually beneficial research prospects in these areas. What has been accomplished to date, described in this article, is encouraging and sets the stage for future collaboration.

KEYWORDS Hepatology, liver transplant, health, medicine, science, Cuba, USA

disease, after colon cancer, and are a major hospital discharge diagnosis.[6] The main causes of chronic hepatitis and cirrhosis in Cuba are the same as in other countries in the Americas Region: viral infections (particularly hepatitis $C$ ) and alcohol.[7] Although hepatitis $B(\mathrm{HBV})$ is a leading cause in many countries, it is not in Cuba, where incidence and prevalence of hepatitis $B$ have been decreasing because of a national program to vaccinate at-risk groups and people aged $<25$ years.[8]

Cuba uses a multidisciplinary and intersectoral approach to finding scientific and technological solutions to resolve, or at least mitigate, the problem of chronic liver disease. The biotech and medical/pharmaceutical industries have been key to providing products and technological resources.[9]

Hepatology, which is relatively new in Cuba, has seen advances in diagnosis, research, and clinical and surgical practice. Various lines of research have resulted from scientific exchange between gastroenterologists and researchers from the former Western Havana Scientific Pole (a group of institutions, now under BioCubaFarma, dedicated to the full research and development cycle aimed at promoting biotechnological development and advanced technologies to resolve health and nutrition problems, while generating revenue for Cuba from competitive products).[10] Joint research beginning in the 1980s led to Cuban production of interferon (in its various forms) for treatment of viral hepatitis $B$ and $C$, and the hepatitis $B$ vaccine, HeberbiovacHB,[11-13] which helped reduce incidence and prevalence of liver infections.

Other research explores the natural history of hepatic cirrhosis, hepatocellular carcinoma, viral hepatitis, nonalcoholic fatty liver, alcoholic liver disease, autoimmune liver diseases and inherited diseases, and new technologies are being invented to improve their diagnosis.[14-19] Liver transplantation began in Cuba in 1986 but was discontinued in the early 1990s. Since the national liver transplantation program in Cuba was restarted in 1999, $>400$ liver transplants have been performed, over 80 of them in patients aged <18 years.[20] Although scientific policies are a priority in Cuba and important resources are being invested for 
health research, the US economic embargo and other factors have created severe economic limitations, so such scientific and technical cooperation and exchange activities with developed nations with resources in topics of shared interest are welcome opportunities.

\section{COLLABORATION}

Cuba's Ministry of Public Health and the US Department of Health and Human Services have agreed to collaborate on health issues. This new stage of bilateral diplomatic relations, which were reestablished in 2015, motivated joint medical research in multiple areas.[21] The countries' geographical proximity is well suited for exchange projects, programs, and health strategies to benefit both populations. Several US scientists have called for lifting restrictions imposed on Cuba, mainly in the areas of health and science.[22,23]

Collaboration in gastroenterology, and specifically hepatology, predated renewal of diplomatic relations. It has focused on developing Cuban hepatologists' and transplantologists' technical skills in US settings, sharing areas for learning and discussion with US professionals about medical and gastroenterology practice in Cuba, and Cuba's National Health System (NHS). Exchange began in 1996 with visits by US gastroenterologists from Boston and Portland (ME) to explore Cuban gastroenterologists' research and their clinical and procedural advances (Table 1 ), having limited previous knowledge of Cuban medicine and gastroenterology, acquired through visits supported by the US Presbyterian Church.

To date, activities have been focused on two main categories: short visits by Cuban gastroenterologists to prestigious US institutions, and participation by specialists at conferences held in both countries with joint clinical and endoscopic work (Table 1). The short visits offered the Cubans new knowledge and skills through the expertise of highly qualified professionals in gastroenterology and digestive endoscopy. As part of the exchange, US specialists donated endoscopic equipment and supplies to Cuban services.
At the same time, Cuba shared its advances in biotechnology for treating acute and chronic viral hepatitis $\mathrm{C}$ with a Cuban biotech product, recombinant interferon alfa-2b, produced by the Genetic Engineering and Biotechnology Center.[24-26] Results were presented at the First Boston-Cuba Gastroenterology Conference (1999).

The first contact between US and Cuban liver transplantation specialists was facilitated in 2009 by Global Links (a Pittsburghbased nonprofit organization that provides large-scale humanitarian medical aid) and consisted of a visit by professionals from the pediatric transplant team at William Soler University Children's Hospital in Havana to an equivalent service in the USA (Table 1).[27]

One important result of these exchanges was the inclusion of Cuba's Gastroenterology Institute in the Global Alcoholic Liver Disease Survey (GLADIS),[28] which was coordinated by Dr Ramón Bataller (then of the Division of Gastroenterology and Hepatology at University of North Carolina at Chapel Hill). This research, conducted in 2015, explored possible clinical and etiological differences among patients with chronic liver disease. The research involved 3000 patients from 16 gastroenterology and hepatology centers in 23 countries. The study also collected anthropometric, etiologic and clinical data on 100 patients admitted consecutively with early liver disease (not cirrhosis or decompensated disease) seen as outpatients and 100 patients who were hospitalized for liver disease.

The 2017 Hepatology Symposium in Havana attracted renowned US academics, opinion leaders and experts, most of whom were members of the American Gastroenterology Association, American Association for the Study of Liver Disease (AASLD), American College of Gastroenterology, European Association for the Study of Liver Disease, or the American Society of Transplantation (Table 1). Relationships established at this conference enabled a Cuban delegation to attend The Liver Meeting (Table 1), a key AASLD event and the main conference in the field of hepatology, which each year brings together over 9500 hepatologists from around the world.

\begin{tabular}{|c|c|c|c|}
\hline Year & Type of activity & Country & Actions/Results \\
\hline 1996 & $\begin{array}{l}\text { US gastroenterologists visit Hermanos Ameijeiras Clini- } \\
\text { cal-Surgical Teaching Hospital }\end{array}$ & Cuba & $\begin{array}{l}\text { Presentation of scientific results Planning of new meetings in both } \\
\text { countries for collaboration }\end{array}$ \\
\hline 1998 & 3rd Cuban-US gastroenterology conference & Cuba & $\begin{array}{l}\text { Joint endoscopies } \\
\text { Agreements granting Cubans short US placements }\end{array}$ \\
\hline 1999 & $\begin{array}{l}\text { Short placements of Cuban specialists at Lahey } \\
\text { Hospital Medical Center and Beth Israel Medical Center }\end{array}$ & USA & $\begin{array}{l}\text { Endoscopies, rounds, joint endoscopic retrograde } \\
\text { cholangiopancreaticography }\end{array}$ \\
\hline 1999 & 1st Boston-Cuba Gastroenterology Conference & USA & Discussion of scientific results with Cuban biotech products \\
\hline 2009 & $\begin{array}{l}\text { Short placements_of Cuban hepatologists and trans- } \\
\text { plant specialists at Children's Hospital of Pittsburgh } \\
\text { (University of Pittsburgh Medical Center) }\end{array}$ & USA & $\begin{array}{l}\text { Knowledge about new procedures, treatments, managing intensive } \\
\text { therapy, hepatology, anesthesiology, immunology, emergency room } \\
\text { and abdominal organ transplants }\end{array}$ \\
\hline 2015 & Global Alcoholic Liver Disease Survey (GLADIS) & Cuba & $\begin{array}{l}\text { Inclusion of Cuba in US-coordinated, international, multicenter } \\
\text { research on alcoholic liver disease }\end{array}$ \\
\hline 2017 & 2017 Hepatology Symposium & Cuba & $\begin{array}{l}\text { Exchanges on liver transplantation: handling complications, results } \\
\text { from living-donor transplants and variants, new immunosuppressive } \\
\text { therapies. For liver disease: HBC treatment and results of direct- } \\
\text { acting antivirals, management of hepatocellular carcinoma, } \\
\text { nonalcoholic fatty liver disease, alcoholic liver disease }\end{array}$ \\
\hline 2017 & The Liver Meeting & USA & $\begin{array}{l}\text { Presentation of experience and impact of Cuba's HBC prevention } \\
\text { and treatment program. Inclusion of Cuba in IC-HEP Council }\end{array}$ \\
\hline
\end{tabular}

HBC: hepatitis B and C IC-HEP: International Coalition of Hepatology Education Providers 
The support of organizations dedicated to providing the latest information and facilitating clinical education on liver disease to health professionals was critically important for these exchanges, including the International Coalition of Hepatology Education Providers, the Liver Health Connection and the Chronic Liver Disease Foundation, as well as Cuba's Gastroenterology Institute and the Cuban Gastroenterology Society.

\section{ANALYSIS}

Cuba's NHS guarantees free and universal health care. The system is pyramidal, based on primary care, where family doctor-and nurse offices and multispecialty polyclinics focus on disease prevention and promotion of health, referring patients to secondary-specialty care when necessary. Tertiary care institutions conduct research and handle more advanced techniques and procedures,[29] including liver transplants.

These characteristics of the Cuban health care system offer excellent opportunities for large-scale collaboration and research projects. Doctors and researchers are well-trained and qualified, suported by a national network of health care facilities with a uniform structure and a consolidated hospital management system that offers diagnostic and therapeutic options under ethical principles established by accredited ethics committees in all institutions. This structure favors obtaining reliable data regarding morbidity and mortality rates for different diseases, as well as other health statistics. Reliable records are kept of all research conducted.[30]

In this context, Cuba offers favorable conditions for clinical trials in patients with chronic liver conditions (such as viral hepatitis, nonalcoholic fatty liver disease and alcoholic liver disease) who have not received specific antiviral treatment or have not responded favorably to antivirals available in Cuba. There have been no clinical trials to date involving both countries. Such trials would be beneficial for assessing direct-acting antivirals for treatment of chronic hepatitis $\mathrm{C}$ infection (including patients with end-stage kidney disease) and certain forms of ablative treatment of hepatocellular carcinoma, in which the USA has experience.

The First Boston-Cuba Gastroenterology Conference allowed US specialists to appreciate Cuban advances in gastroenterology and hepatology, with use of Cuban therapeutic biotech products. This led to the first inclusion of Cuban doctors in the American Gastroenterology Association. For their part, Cubans updated their knowledge of technological and scientific developments in gastroenterology and increased clinical and endoscopic skills vital to quality practice.

The 2009 visit by Cuban transplantologists to the pediatric transplant unit in the Children's Hospital of Pittsburgh (University of Pittsburgh Medical Center) did not lead to changes in medical or surgical protocols in place in Cuban transplantation services since 2004 , but did bring about smaller changes in procedures for deep vein thrombosis prophylaxis and pediatric anesthesia. The focus of Cuba's medical system and its advances in hepatology, hepatobiliary surgery and pediatric transplantation were presented. Another highlight of the experience was the opportunity for Cubans to meet Dr Thomas Earl Starzl, known as the father of modern transplantology, who performed the first liver transplant; his innovations in surgery, immunology and immunosuppression revolutionized the field.[31]
GLADIS showed that referrals of patients with liver disease to specialty care varied significantly by country. Referrals of alcoholic patients occurred in more advanced stages than for patients with viral or nonalcoholic liver disease. Specific patterns were recognized in Cuban patients on diagnosis and referral to specialized services. Patients with autoimmune hepatitis, HBV and HBV+HCV coinfection were diagnosed in early stages, while alcoholic liver disease, alone or associated with $\mathrm{HCV}$, was diagnosed in advanced stages, mostly with complications of hepatic cirrhosis.[28] Early diagnosis of liver disease from HBV infection is associated with Cuba's viral hepatitis prevention and control program in primary care, which includes actions in surveillance, awareness promotion, vaccination and prevention in general. The program's impact on controlling hepatitis from HBV has been documented.[3234] However, despite preventive actions, HCV is still a leading cause of advanced liver disease and liver transplantation in Cuba.[35]

Alcoholism is a mounting challenge in the Americas, which has higher levels of alcoholism, on average, than the rest of the world. [36] According to Cuba's 2014 Multiple Indicator Cluster Survey, $46.5 \%$ of men and $19.2 \%$ of women aged $15-49$ years report consuming alcohol in the past month.[37]

Including Cuba in GLADIS was a progressive step in addressing alcohol-related liver disease; its results warn of the threat of a disease that starts silently, goes unnoticed, and ends fatally due to complications. Early detection and timely referral to specialized centers are needed for these patients, as part of strategies that can be shared in collaboration between Cuba and the USA.

US specialists participating in the 2017 Hepatology Symposium learned how Cuba's health care system is organized, and about hepatology and liver transplantation work in Cuba. They also became familiar with progress in biotechnology and pharmaceuticals, closely linked to progress in hepatology, and learned about Cuba's national health care programs, such as those for viral hepatitis prevention and control, immunizations, HIVIAIDS, and others that connect the NHS with biotechnology institutions This exchange was enriched with an opportunity to visit institutions dedicated to hepatology and liver transplantation in Cuba, such as the Gastroenterology Institute and the MedicalSurgical Research Center.

Cuba's inclusion for the first time in The Liver Meeting was an opportunity for delegates to highlight Cuba's experience in and impact on the prevention and treatment of hepatitis B,[35] presenting the current state of hepatology in Cuba and outlining prospects for future collaboration. These meetings between Cuban and US specialists also facilitated Cuba's incorporation into the Latin American Association for the Study of the Liver (ALEH) and the International Coalition of Hepatology Education Providers, two leading organizations in the study of liver disease. The Chair of the Cuban Gastroenterology Society attends meetings of ALEH's Board of Directors.

These exchanges are a good starting point for Cuba's inclusion in leading scientific organizations, for sharing knowledge of Cuban biotech products for treatment of liver disease, and for Cuba to become a partner in multinational research on liver disease. In this regard, such contacts must be further developed to open 
doors to joint US-Cuba research and publication of scientific articles with authors from both countries within an official framework of cooperation. Professionals from both countries dedicated to researching liver disease and liver transplantation would benefit from continuing and expanding training through exchanges at high-level institutions, as well as skill development in cutting-edge diagnostic, therapeutic and surgical techniques.

\section{CONCLUSIONS}

Progress in hepatology and liver transplantation has helped Cuba overcome great health challenges. The US-Cuban exchange has contributed to new knowledge for both countries. Cuban professionals have gained access to high-level scientific information and clinical practice, while their US colleagues have learned and seen evidence of the development of the health sector in Cuba. This has helped resolve doubts and deepen understanding of Cuba's reality and prospects for research in this area, sowing the seeds for future collaboration.

\section{ACKNOWLEDGMENTS}

The authors thank Yenisley Ortega Betancourt for her valuable contribution to drafting and correcting this manuscript. - 1/

\section{REFERENCES}

1. Mokdad AA, López AD, Shahraz S, Lozano R, Mokdad AH, Stanaway J, et al. Liver cirrhosis mortality in 187 countries between 1980 and 2010: a systematic analysis. BMC Med. 2014 Sep 18;12:145.

2. GBD 2015 Mortality and Causes of Death Collaborators. Global, regional, and national life expectancy, all-cause mortality, and causespecific mortality for 249 causes of death, 1980-2015: a systematic analysis for the Global Burden of Disease Study 2015. Lancet. 2016 Oct 8;388(10053):1459-544.

3. Sarin SK, Maiwall R. Global burden of liver disease: a true burden on health sciences and economies [Internet]. Milwaukee: World Gastroenterology Organization; 2012 [cited 2017 Nov 3]; [about 3 screens]. Available from: http://www .worldgastroenterology.org/publications/e-wgn/ e-wgn-expert-point-of-view-articles-collection/ global-burden-of-liver-disease-a-true-burden-on -health-sciences-and-economies

4. Scaglione S, Kliethermes S, Cao G, Shoham D, Durazo R, Luke A, et al. The epidemiology of cirrhosis in the United States: a population-based study. J Clin Gastroenterol. 2015 Sep;49(8):690-6.

5. Xu J, Murphy SL, Kochanek KD, Bastian BA. Deaths: Final Data for 2013. Natl Vital Stat Rep [Internet]. 2016 Feb 16 [cited 2017 Nov 3];64(2):1-119. Available from: https://www.cdc .gov/nchs/data/nvsr/nvsr64/nvsr64_02.pdf

6. National Health Statistics and Medical Records Division (CU). Anuario Estadístico de Salud 2016 [Internet]. Havana: Ministry of Public Health (CU); 2017 [cited 2017 Jul 29]. 206 p. Available from: http://files.sld.cu/dne/files/2017/05/Anua rio_Estad\%C3\%ADstico_de_Salud_e_2016 edici\%C3\%B3n 2017.pdf. Spanish.

7. Tsochatzis EA, Bosch J, Burroughs AK. Liver cirrhosis. Lancet. 2014;383(9930):1749-61.

8. National Health Statistics and Medical Records Division (CU). Indicadores del Estado de Salud de la Población. Series de Tiempo. CUBA 19702013 [Internet]. Havana: Ministry of Public Health (CU); 2014 Jun [cited 2017 Jul 30]. 73 p. Available from: http://files.sld.cu/dne/files/2014/06/ series-de-tiempo-cuba-1970 2013.pdf. Spanish.

9. Álvarez Blanco AS, Cabrera Cruz N, Toledo Fernández AM, Arteaga García A. El sistema de ciencia e innovación tecnológica en salud y su universalización a todo el sistema nacional de salud. Educ Méd Super. 2009 Jan-Mar;23(1):1-10. Spanish.

10. Simeón Negrín RE. La ciencia y la tecnología en Cuba. Rev Cubana Med Trop. 1997;49(3):15360. Spanish.

11. Castellanos-Fernández MI, González-García A, Nodarse-Cuní H, Calzadilla-Bertot L, MartínezPérez Y, Sánchez Rodríguez YA, et al. An open, non-controlled clinical study to assess the efficacy and safety of the recombinant human alpha $2 \mathrm{~b}$ pegylated interferon PEG-Heberon ${ }^{\circledR}$ plus ribavirin for the treatment of chronic hepatitis $\mathrm{C}$ virus infection in Cuban patients. Biotecnol Apl. 2015 Oct-Dec;32(4):4201-7.

12. Delgado G, Galindo MA, Rodríguez L, Díaz M. Vaccination Strategies Against Hepatitis B And Their Results: Cuba and the United States, 2003. MEDICC Rev [Internet]. 2004 [cited 2017 Sep 21];6(1). Available from: http://www.medicc.org/ publications/medicc_review/1004/pages/cuban medical literature.html

13. Center for State Control of Medicines, Equipment and Medical Devices. Registro vacuna antihepatitis B recombinante HEBERBIOVAC $\mathrm{HB} \otimes$ [Internet]. Havana: Center for State Control of Medicines, Equipment and Medical Devices; 2013 Dec 17 [cited 2017 Sep 02]. 5 p. Available from: http://www.cecmed.cu/sites/default/ files/adjuntos/rcp/biologicos/rcp_heberbiovac-hb 2013-12-17.pdf. Spanish.

14. Gómez EV, Rodríguez YS, Bertot LC, González AT, Pérez YM, Soler EA, et al. The natural history of compensated HCV-related cirrhosis: a prospective long-term study. J Hepatol. 2013 Mar;58(3):434-44.

15. Castellanos Fernández MI, López Díaz Y, Sánchez Rodríguez YA, Lazo Del Vallín S, Hernández Perera JC. Particularidades del carcinoma hepatocelular en los pacientes con cirrosis hepática. Rev Cubana Med. 2011Jan-Mar;50(1):57-69. Spanish.

16. Vilar-Gómez E, Martínez-Pérez Y, CalzadillaBertot L, Torres-González A, Gra-Oramas B, González-Fabian L, et al. Weight loss through lifestyle modification significantly reduces features of nonalcoholic steatohepatitis. Gastroenterology. 2015 Aug;149(2):367-78.

17. Dorta Guridi Z, Castellanos-Fernández MI, DueñasCarrera S, Martínez Donato G, Valenzuela Silva C, Cinza Estévez Z, et al. Clinical Evaluation of Terap C Vaccine Candidate in Combined Treatment with Interferon and Ribavirin in Patients with Hepatitis C. Curr Ther Res Clin Exp. 2017 Apr 27;85:20-8.

18. Castellanos-Fernández MI, Dorta Guridi Z, CondeEduardo Leda Patricia DS, Galbán García E, Arús Soler E, Martínez Pérez Y. Current Condition of Chronic Hepatitis B Virus Infection in Cuban Adults. Curr Ther Res Clin Exp. 2017 May 4;85:15-9.

19. Castellanos-Fernández MI, la Rosa Hernández D, Cabrera Eugenio DE, Palanca W, Dorta Guridi Z, González Fabián L. Diagnosis and Treatment of Autoimmune Liver Diseases in a Tertiary Referral Center in Cuba. Curr Ther Res Clin Exp. 2017 Apr 7;85:8-14. Available from: http://www.revmie.sld.cu/index.php/ mie/article/view/420/html_146. Spanish.

20. Abdo Cuza A. Trasplante hepático en Cuba: mucho más que una suma de anécdotas. Rev Cubana Med Intens Emerg [Internet]. 2018 AprJun [cited 2018 Apr 06];17(2):1-5. Avaliable from: http://www.revmie.sld.cu/index.php/mie/article/ view/420/html_146. Spanish.

21. Keck CW. The United States and Cuba-Turning Enemies into Partners for Health. N Engl J Med. 2016 Oct;375(16):1507-9.
22. Demain AL. Scientific links with Cuba flourished despite US embargo. Nature. 2009 Feb 26;457(7233):1079.

23. Abreu MT, Damas OM, Piñol-Jiménez FN, Cañete-Villafranca R. United States-Cuba Research Collaborations: Opening Bridges for Gastroenterology. Gastroenterology. 2017 May;152(6):1267-9.

24. Arús Soler E, Rivera Reimón L, Infante Velázquez $M$, Pérez Lorenzo $M$, Soto Argüelles G, Gra Oramas B, et al. Tratamiento de la hepatitis viral aguda $\mathrm{C}$ con interferón alfa $2 \mathrm{~b}$ recombinante: ensayo clínico. Rev Cubana Med. 2000;39(1):21-9. Spanish.

25. Arús Soler E, Rivera Reimón L, Fernández Naranjo A, Infante Velázquez M, Jorge Díaz R, Soto Argüelles $\mathrm{G}$, et al. Tratamiento de la hepatitis crónica $\mathrm{C}$ con interferón alfa $2 \mathrm{~b}$ recombinante: Ensayo clínico controlado aleatorizado. Rev Cubana Med. 2000 Jan-Mar;39(1):12-20. Spanish.

26. Infante Velázquez $M$, Arús Soler $E$, Fernández Naranjo A, Grá Oramas B. Hallazgos clínicos, bioquímicos y morfológicos en 103 pacientes con anticuerpos contra el virus de la hepatitis $C$. Rev Cubana Med. 1998 Apr-Jun;37(2):66-71. Spanish.

27. Global Links. Cuban Pediatric Transplant Team Hosted by Pittsburgh-Based Global Links in First U.S. Visit. Pittsburgh: Global Pittsburgh News [Internet]. 2009 Oct 28 [cited 2018 Apr 2]; [about 2 screens]. Available from: http://global pittsburgh.blogspot.cl/2009/10/pittsburgh-based -global-links-hosts.html

28. Shah N, Cots $M$, Zhang C, Zahiragic N, Yu Y, Yacoub M, et al. LBP-529-Worldwide lack of early referral of patients with alcoholic liver disease: results of the global alcoholic liver disease survey (GLADIS). J Hepatol. 2017;66(1):S107-S8

29. Campion EW, Morrissey S. A Different ModelMedical Care in Cuba. N Engl J Med 2013; 368:297-9.

30. Álvarez Sintes R, Barcos Pina I. Formación y perfeccionamiento de recursos humanos en el sistema de salud cubano para cobertura sanitaria universal. Rev Cubana Salud Pública. 2015;41 (Suppl. 1). Spanish

31. Fung JJ, Everson GT, van Thiel D. Obituary: The Impact of Thomas Earl Starzl, MD, PhD. Gastroenterology. 2017 Jun;152(8):1805-6.

32. World Health Organization. Global policy report on the prevention and control of viral hepatitis in WHO Member States. Geneva: World Health Organization; 2013.

33. Delgado González G, Galindo Sardiña MA, Rodríguez Lay L, Díaz González M. Vaccination strategies against hepatitis $B$ and their results: Cuba and the United States, 2003. MEDICC Rev [Internet]. 2003 [cited 2017 May 10];5(1). Available from: http://www.medicc.org/publica tions/medicc_review/1004/pages/cuban_medical _literature.html 
34. Díez-Padrisa N, Castellanos LG; PAHO Viral Hepatitis Working Group. Viral hepatitis in Latin America and the Caribbean: a public health challenge. Rev Panam Salud Pública. 2013 Oct;34(4):275-81.

35. Samada Suárez M, Hernández Perera JC, Ramos Robaina L, Barroso Márquez L, Gonález Rapado L, Cepero Valdés M, et al. Factors that predict survival in patients with cirrhosis considered for liver transplantation. Transplant Proc. 2008 Nov;40(9):2965-7.

36. Pan American Health Organization. Informe de situación regional sobre el consumo de alcohol y la salud en las Américas [Internet]. Washington, D.C.: Pan American Health Organization; World Health Organization; 2015 [cited 2017 Sep 3]. 80 p. Available from: http:// www. paho.org/hq/index.php?option=com content\&view $=$ article\&id $=11108 \% 3$ A2015-regio nal-report-alcohol-health\&catid $=1893 \% 3$ Anews \&ltemid=41530\&lang=es. Spanish.

37. National Health Statistics and Medical Records Division (CU). Cuba. Encuesta de Indicadores Múltiples por Conglomerados 2014 [Internet]. Havana: UNICEF; 2015 [cited 2017 May 10]. Available from: https://www.unicef.org/cuba/ mics5-2014-cuba.pdf. Spanish.

\section{THE AUTHORS}

Marlen I. Castellanos-Fernández (Corresponding author: mcastell@infomed.sld.cu), gastroenterologist with a doctorate in medical sciences. Full professor and senior researcher, Teaching and Research Department, National Gastroenterology Institute (ING) and Medical University of Havana (UCMH), Cuba.

Mirtha Infante-Velázquez, gastroenterologist with a doctorate in medical sciences. Full professor and senior researcher, Teaching and Research Department, ING and UCMH, Havana, Cuba.

Enrique Arús-Soler, gastroenterologist with a doctorate in medical sciences. Full professor, senior researcher and consultant, ING and $\mathrm{UCMH}$, Havana, Cuba.

Marcelo Kugelmas, gastroenterologist. Director, hepatology and research, South Denver Gastroenterology, Denver, USA; clinical associate professor, University of Colorado, Aurora, USA.

Ramón Bataller, gastroenterologist and hepatologist. Professor, University of Pittsburgh, Pittsburgh, USA.

Ramón Villamil-Martínez, physician with dual specialties in family medicine and pediatric surgery. Head of pediatric liver transplantation, William Soler University Children's Hospital and UCMH, Havana, Cuba.

Zaily Dorta-Guridi, gastroenterologist with a doctorate in medical sciences. Full professor and associate researcher in hepatology, ING and $\mathrm{UCMH}$, Havana, Cuba.

Caridad Ruenes-Domech, gastroenterologist with a master's degree in higher medical education. Associate professor and Director, ING and UCMH, Havana, Cuba.

Submitted: October 3, 2017

Approved for publication: March 22, 2018

Disclosures: None.

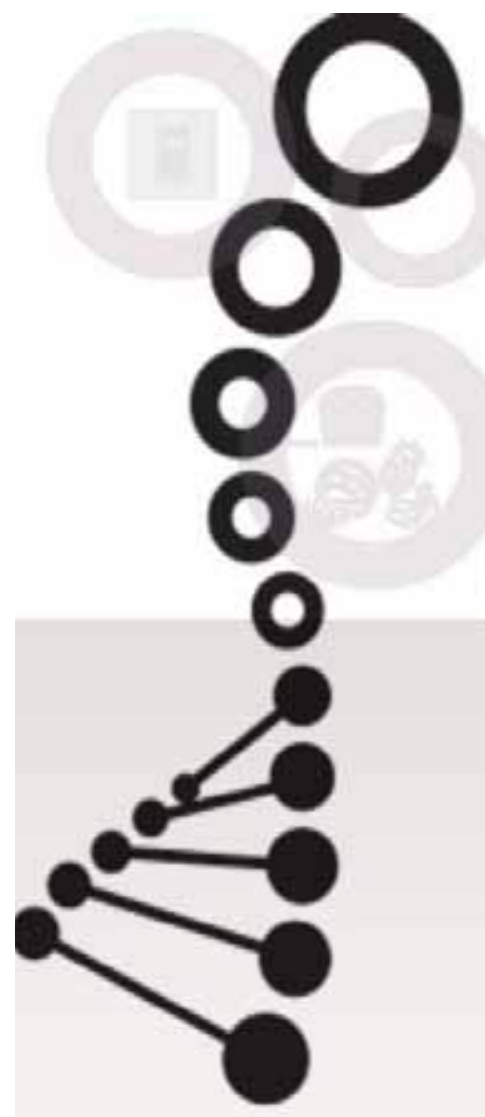

International Congress:

Controlling Diabetes and its More Severe Complications

\section{Plaza América Convention Center, Varadero, Cuba December 10-14, 2018}

Main topics:

- Diabetes prevention

- Diabetes as metabolic syndrome

- Obesity and diabetes

- Diabetes types 1 and 2: global medical updates in early detection, metabolic control and treatment

- Gestational diabetes

- Comprehensive care of diabetes in pregnancy

- Growth factors and wound healing

- Diabetic foot ulcer

- Postmarketing pharmacosurveillance of Heberprot-P in Cuba

Information hptcongress@cigb.edu.cu http://hptcongress.cigb.edu.cu/en/365-2/ 